\author{
T. Momot, I. SinCHESKUL, K. SAVENKO, K. BUKRIEIEVA
}

\title{
BALANCED MANAGEMENT OF STAKEHOLDER RELATIONSHIPS IN THE HEATING SPHERE
}

The article is devoted to the study of theoretical principles and practical aspects of managing relationships with stakeholders of municipal heating companies. The subject of the study is a set of theoretical, methodological and practical aspects for ensuring balanced management of relations with the stakeholders of municipal heating companies. The purpose of the article is to develop theoretical and methodological provisions and substantiate practical recommendations for ensuring a balanced management of these relationships. Tasks of work: to research and systematize the conceptual apparatus of ensuring the management of relations with the stakeholders of municipal heat companies; to justify the organizational principles of managing these relationships; to offer analytical and applied support for managing them on a balanced scorecard. During the research were used methods: abstract-logical analysis, theoretical generalization, systemic and statistical analysis, systemic and statistical analysis, economic-mathematical methods, graphical method. The paper generalizes the economic characteristics of the activity of district heating utilities and develops the directions of development of relations with stakeholders in the process of reforming the housing and municipal services of Ukraine on the basis of the analysis of the efficiency of the municipal heating companies in developed countries of Europe. Strategic directions for the development of district heating utilities by providing balanced stakeholder relationship management are substantiated. Conclusions. It is proposed to use a balanced scorecard, which allows, based on the evaluation of financial and non-financial indicators of enterprise performance, to identify trends of change of each of four key areas of activity to achieve the goal of MHC in meeting the public needs of consumers, profit for the development of the enterprise, ensure the interests of its employees and their satisfaction economic and social needs based on stakeholder reconciliation.

Keywords: municipal heating; municipal heating companies; relationship management; stakeholders; energy efficiency; organizational and economic model.

\section{Introduction}

Municipal heating is one of the leading places in the system of priorities for ensuring the energy security of the country, improving the energy efficiency of the functioning of heat supply systems, creating and improving the market of heat energy and protecting the rights of consumers and employees of the heat supply sector. This is due to the objective conditions of functioning of the heat supply systems, characterized by such features as: the need to generate heating energy directly near the objects of its implementation, as well as the inability to accumulate it; presence of division of economic activity in the sphere of heat supply into production, transportation and supply of heat energy; the existence of various technologies for the production of heating energy, including the technologies of cogeneration of electricity and heat and the use of non-traditional and renewable energy sources; centralized heat supply to consumers from heating power plants and boiler plants that are part of the unified energy system of Ukraine; the existence of heat supply facilities of various forms of ownership; significant seasonal differences in the modes of production and consumption of heat during the year; the special status of subjects of natural monopolies, which most entities in the field of heat supply $[1,2]$.

However, the municipal heating sector was formed in the Soviet times and has a stable tradition of operating under the monopoly on the production, transportation and supply of heat, all entities of which were state or municipal property and still have no significant economic or legislative incentives to form competitive market. In most cases, the production, transportation and supply of heat are performed by one and the same enterprise; tariffs are set by a national commission that regulates public utilities. In such circumstances, businesses are not interested in reducing their costs to ensure that tariffs are reduced for consumers, as tariffs are set on a cost plus basis. As follows, inadequate quality of district heating services, their high cost compared to household income, large unproductive losses of heating energy, deterioration of material and technical base (pipelines of heating networks), as well as lack of centralized hot water services in many cities, are reasons for their lack of consumption. Low level of payment to the district heating company for actually received heating energy [3].

Therefore, finding ways to form a balanced relationship with a wide range of stakeholder (stakeholder) relationships in the heating industry that directly or indirectly influence the process and performance of district heating companies is an important task in ensuring the security of heat supply as one of the necessary security elements. Creation of mechanisms of functioning of an efficient market of heating energy; reduction of harmful effects on the environment; creation of conditions for attracting investments in the development and technical updating of heat supply systems confirms the relevance of the thesis topic.

\section{Analysis of recent studies and publications}

Investigations of the problem of enterprise relationship management are devoted to the works of many foreign researchers, namely: R. Akoffa, I. Ansoff, R. Arbatt, R. Bagozzi, L. Berry, D. Blackwell, A. Braverman, L. Boone, F. Webster, N. Woodcock, P. Gembla, Y. Gordon, K. Granroos, D. Dey, E. Dolan, J. Evans, J. Angela, D. Crevens, D. Kurtz, J.-J. Lambena, R. Lawson, R. Marshak, J. Menning, R. Miller, P. Minnard, W. Ouchy, M. Porter, J. Russell, 
F. Reichelde, P. Seybold, M. Stone, T. Thomas, J. Trout, R. Waterman, R. Freeman, G. Hemel and many others.

Among the domestic scientists-economists who have investigated this problem, it is worth mentioning the work of such researchers as: L. Antoshkin, A. Achkasov, V. Babayev, A. Bochkovsky, O. Vasilyev, T. Danko, O. Zorina, S. Ilyashenko, O. Karlova, N. Kondratenko, O. Kendyukhov, L. Kozhushko, T. Kuznetsova, O. Kuzmak, E. Krykavsky, T. Lepeyko, M. Lesechko, I. Pisarevsky, V. Rossokha, V. Stadnik, O. Suduk, S. Firsova, V. Frolova, G. Tsar, N. Chebanova, D. Stefanych, N. Yaroshevich, L. Yatsishina and others.

The problems of increasing the efficiency of management of municipal enterprises are devoted to the work of such scientists as: A. Allahverdyan, P. Bubenko, V. Vorotyntsev, V. Gavrilenko, S. Galenko, M. Golovchanskaya, O. Dimchenko, O. Ivankov, T. Klebanova, T. Kachala, O. Kotsyurba, L. Lipich, K. Mamonov, M. Miznikov, T. Momot, O. Nagorny, O. Pogaydak, V. Poluyanov, A. Savenko, V. Svitlichna, A. Sidorova, S. Plotnitskaya, Yu. Sharov, L. Shutenko, I. Yaremko and others.

However, in spite of the considerable amount of scientific works and the world experience in the implementation of new management models and technologies of stakeholder management, it is necessary to note the need for further research on the theoretical and methodological provision of balanced management of relationships with key groups of stakeholders in the field of heating power management as an element of strategic management of municipal heating companies (hereinafter referred to as MHC) on the basis of reconciliation of interests and mutually beneficial cooperation. Thus, the theoretical and methodological and applied importance of solving the problems outlined the relevance of the chosen topic, determined the purpose, objectives and direction of the study.

\section{Targets and objectives of the study}

The purpose of the article is to develop theoretical and methodological provisions for ensuring a balanced management of relationships with stakeholders in municipal heating companies.

\section{Study materials and methods}

The theoretical and methodological basis of the research was the scientific works of leading domestic scientists and foreign economists, legislative and regulatory acts of Ukraine in the managing the activities of the subjects of relations in the field of heat supply. During the study such methods as: abstract-logical analysis, dialectical, theoretical generalization, systemic and statistical analysis, cognitive modeling, systemic and statistical analysis, economic-mathematical methods, graphical method was used.

\section{Results of the studies and their discussion}

The problem of ensuring balanced management of relationships with stakeholders is becoming more urgent and needs to be addressed as groups of stakeholders (stakeholders) in the area of heat supply have a direct or indirect impact on the process and performance of municipal heating companies.

The definition of stakeholders as a group (individuals) that can influence the achievement of the organization by its goals or the work of the organization as a whole was introduced by R. Freeman in his paper Strategic Management: A Stakeholder Concept in 1984 [7]. At the same time, the focus is on the role of "interaction", which is seen as the transformation of a set of individual actions into a single set of joint actions. Based on the generalization of scientific approaches [4,5], the content of the concept of "stakeholders in the sphere of heat supply" is defined, defined as groups of subjects of relations that exert economic influence on the heat supply enterprise, connected with the production, transportation, supply and use of heat energy that have an actual impact on management decision-making in the enterprise may contribute to or impede the achievement of the goals of the enterprise, as well as limit its access to certain types of resources, or such influence may be potential him, that result from or operation, or groups of stakeholders. Therefore, in the process of cooperation of the subjects of relations in the sphere of heat supply, cooperation tools are used within the scope of their powers, which allows realizing common goals for ensuring reliable and uninterrupted supply of heat and hot water to all groups of consumers at tariffs, regulated in accordance with the current legislation. The study identifies key stakeholder groups in the field of heat supply, highlighting the tools of interaction within the mandate and the results of their interaction (table 1).

The main stakeholder groups are presented in Fig. 1. It is established that stakeholders may have different types of relations with the enterprise, namely they can: influence the activity of the enterprise, be influenced by the enterprise, and while both being influenced and influence the activity of the enterprise, the interaction between the stakeholders and the enterprise is absent today but may occur in the future.

Management decision-making at enterprises while taking into account the interests of key stakeholder groups enables them to be balanced against the various vectors of MHC interaction with external and internal stakeholders.

Within the framework of the collaborative approach to stakeholder management $[6,8,9]$ the essence of the concept of "ensuring balanced management of relations with the stakeholders of municipal heat supply enterprises" is specified, which forms the basis of the conceptual and terminological apparatus of the research and allows to consider it as a set of processes and actions, management tools and tools based on reconciling the interests of key stakeholder groups in conducting business to achieve balanced managementing decisions. 


\begin{tabular}{|c|c|c|c|c|c|}
\hline 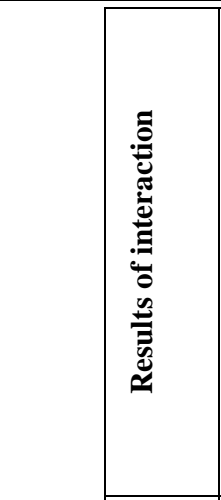 & 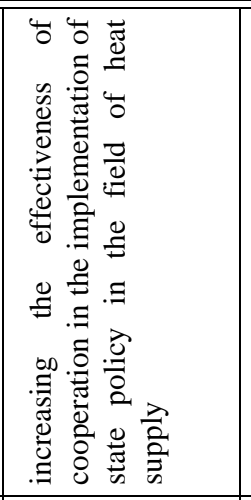 & 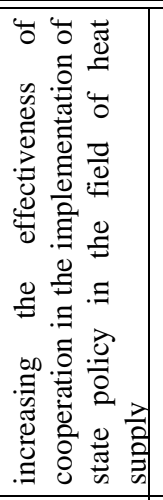 & 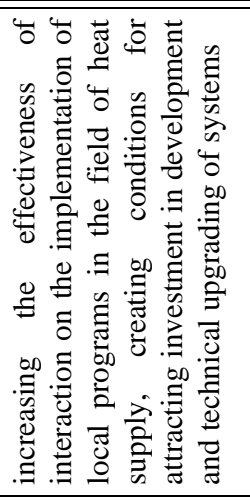 & 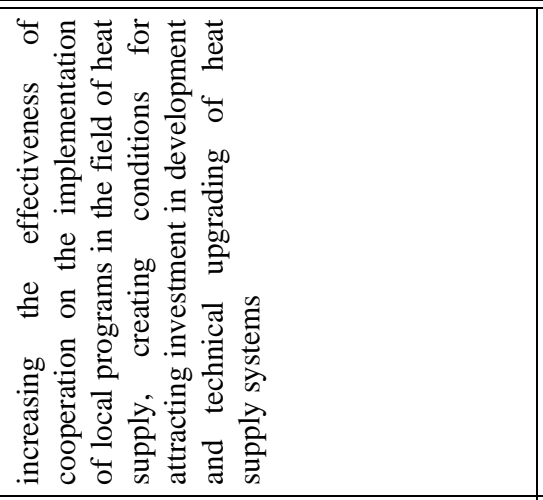 & 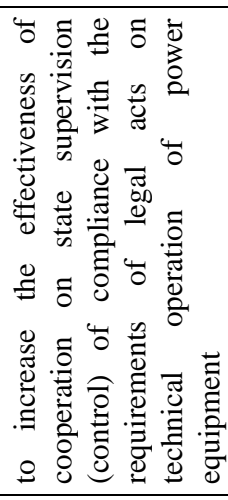 \\
\hline 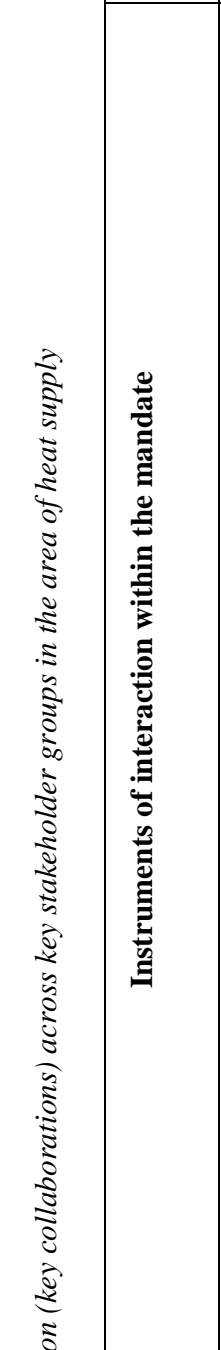 & 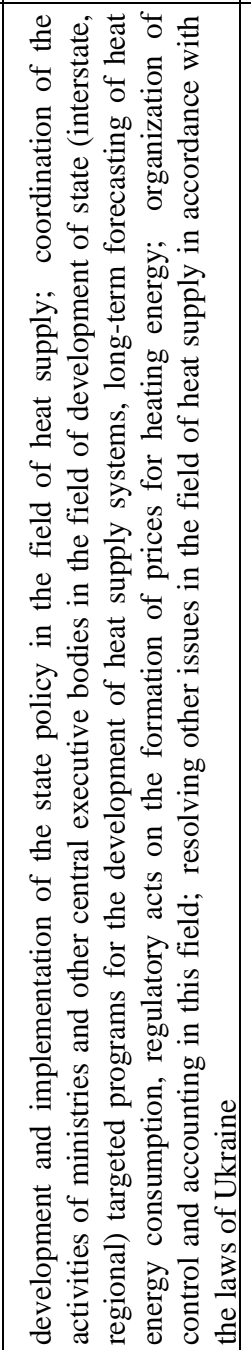 & 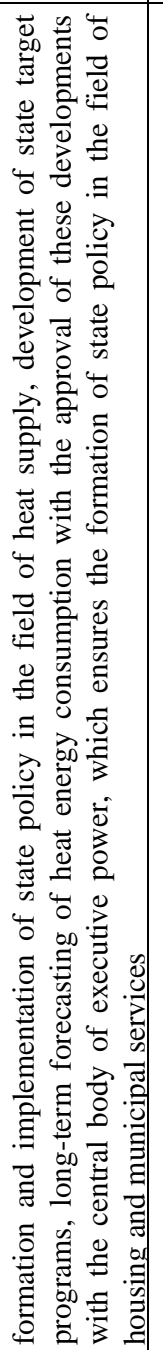 & 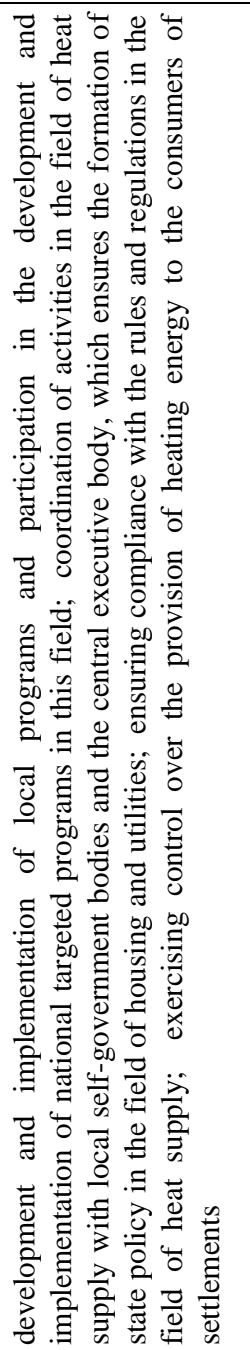 & 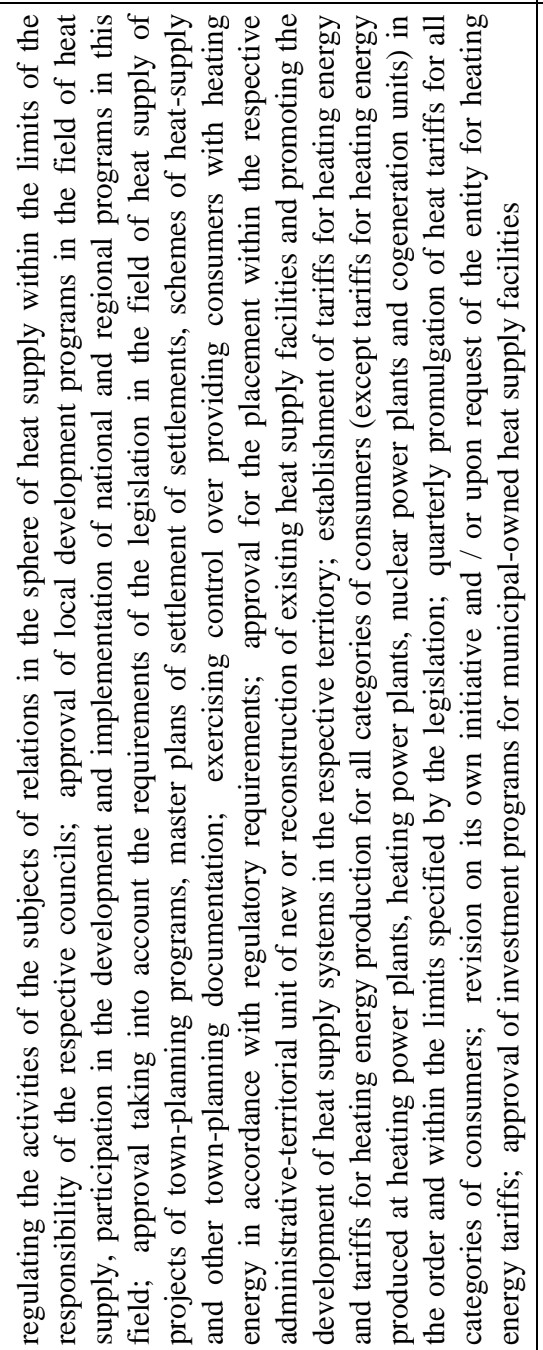 & 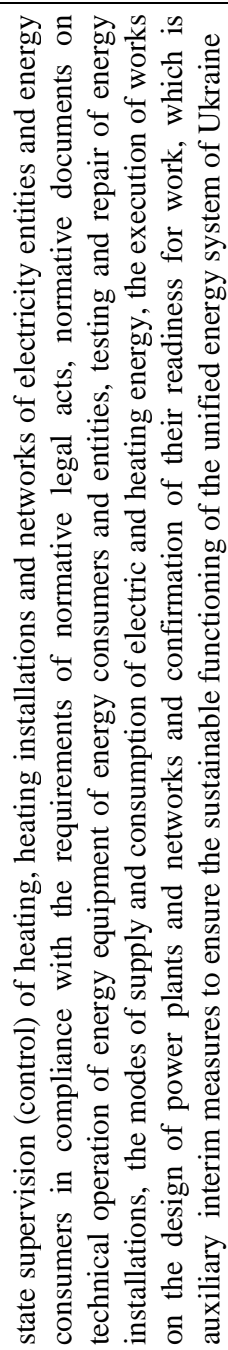 \\
\hline 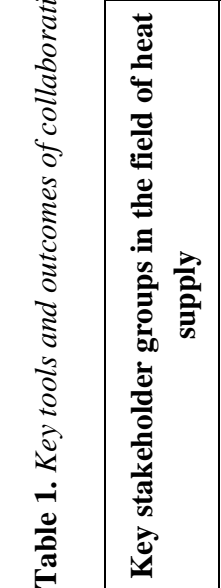 & 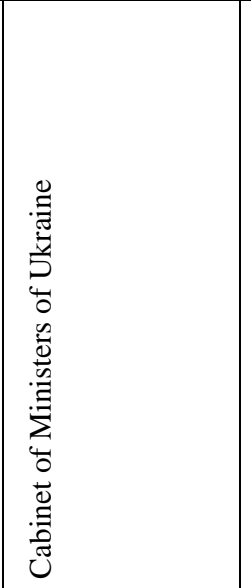 & 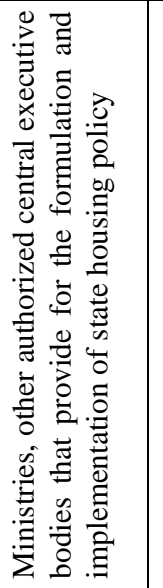 & 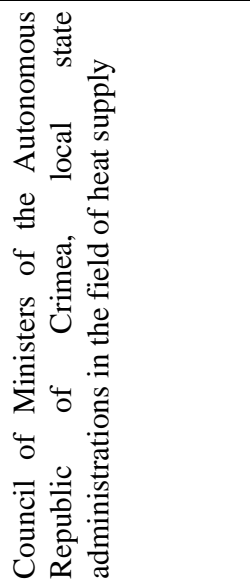 & 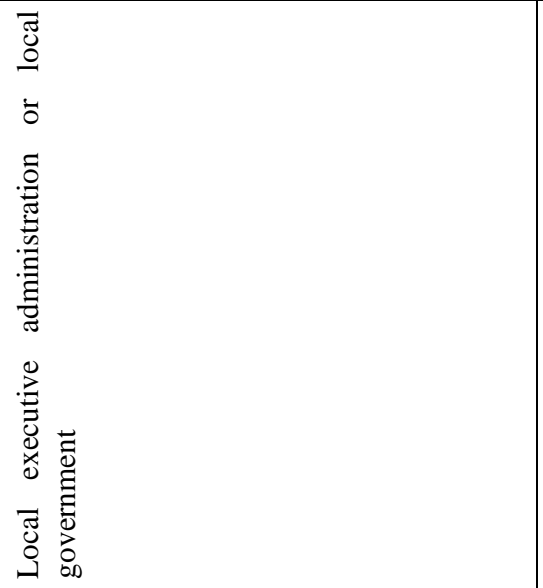 & 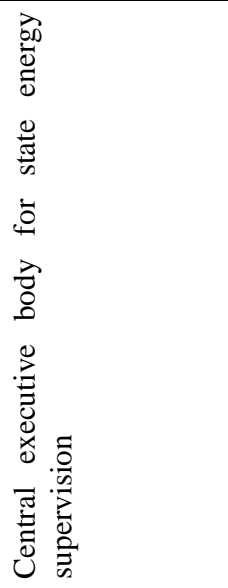 \\
\hline
\end{tabular}




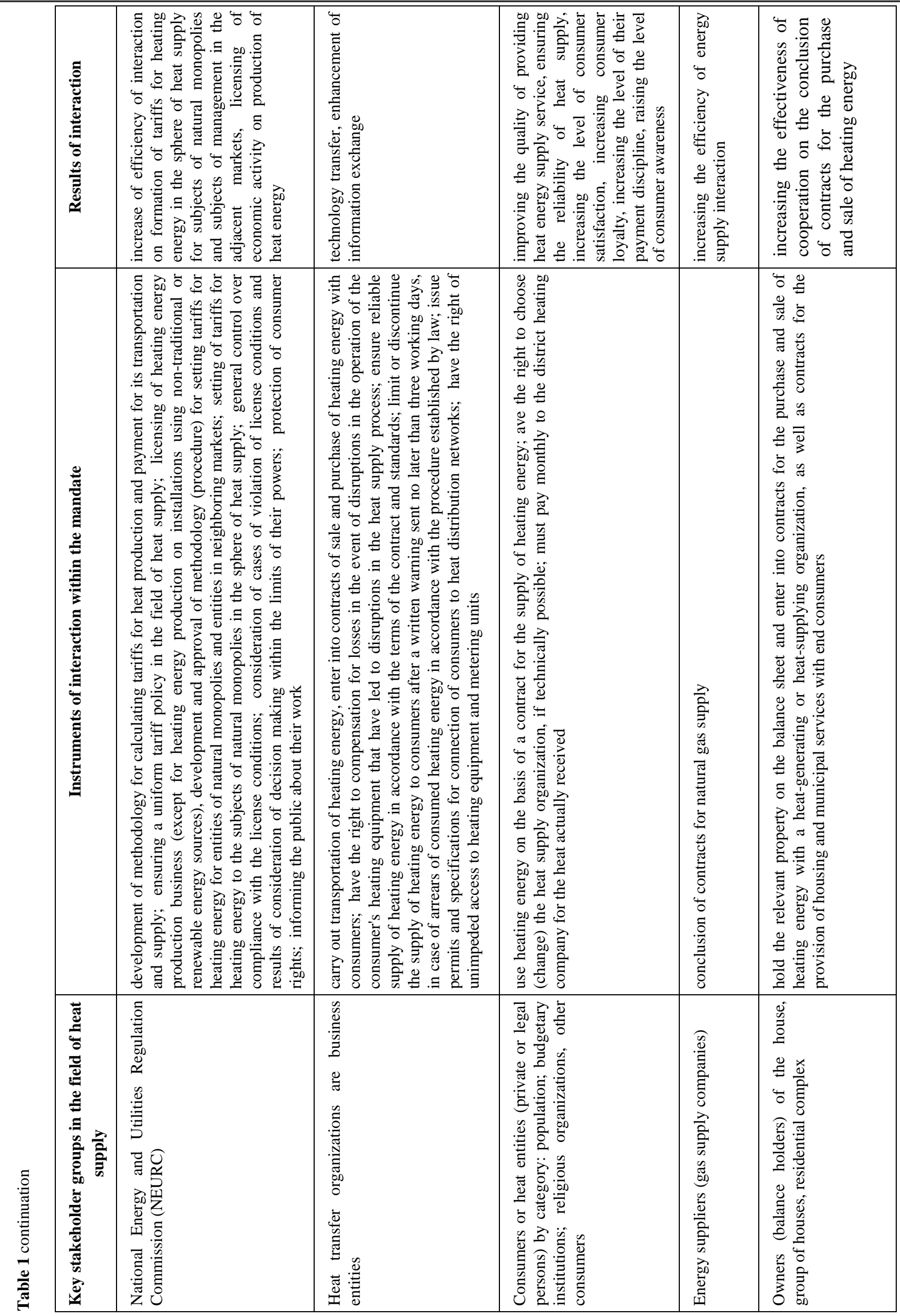




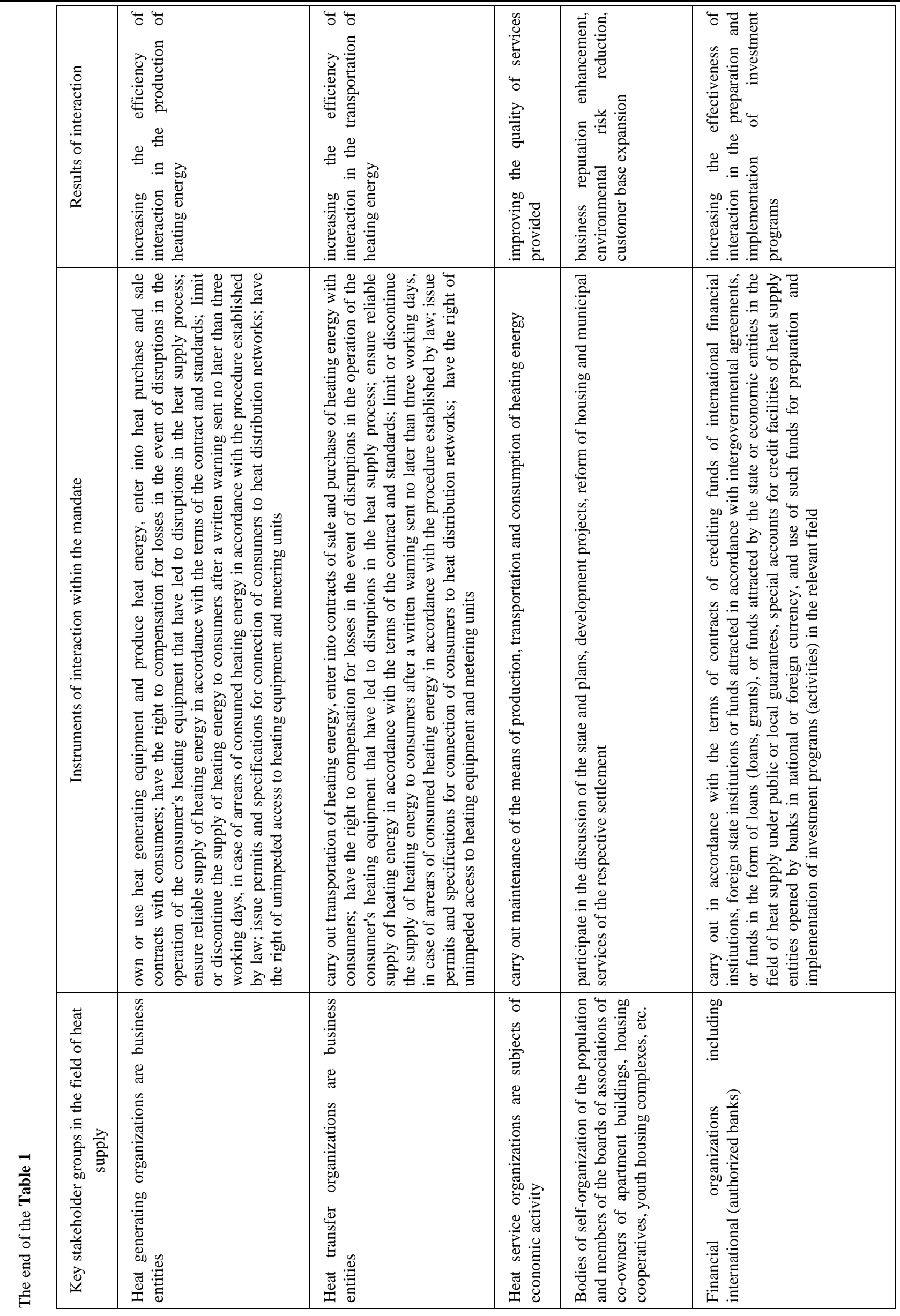


- Cabinet of Ministers of Ukraine

- Ministries and other authorized central bodies of executive power for the formulation and implementation of state housing policy

- Central Executive Body for State Energy Supervision

- National Energy and Utilities Regulation Commission (NERCEP)

- National and International Financial Institutions (Authorized Banks)

- Council of Ministers of the Autonomous Republic of Crimea, local state administrations in the field of heat supply

- Local executive or local government

- Energy suppliers

- Heat generating organizations

- Heat transfer organizations
- District heating organizations

- Heat service organizations

Subjects of heat consumption (natural or legal persons) by categories: population, budgetary institutions, religious organizations, other consumers

Fig. 1. Key stakeholder groups in the field of heat supply

Mutual responsibility of the subjects of relations in the sphere of heat supply for the quality supply of heat energy and its timely payment made it expedient to isolate the marketing component in relation to work with consumers with determination of the level of customer satisfaction with the services, which is determined by the criteria: general satisfaction of MHC work; evaluation of the quality of the services received; estimation of norms and order of payments for the services received; evaluation of the customer service system.

It is proved that MHCs in Ukraine today form a monopolistic market of heat supply, which determines the expediency of determining the priorities and strategic directions of development of the district heating system, the implementation of which will contribute to the sustainable development of housing and municipal services in such areas as: 1) reducing the cost of energy production; 2) intensification of work with consumers to reduce the amount of defaults; 3) reducing actual heat consumption and bringing it closer to effective demand by implementing energy-saving measures in conjunction with consumers.

On this basis, it has been determined that an important area of activity of $\mathrm{MHC}$ in the current conditions is to take into account the factors of the internal and external environment that affect its development, identify potential threats and favorable opportunities for the development of MHC in the future. According to the results of the analysis, the most significant risk factors that influence and in the future may influence the results of the MHC's activity are external factors caused by the state policy on regulation of economic activity of heat supply companies and imperfection of regulatory and legislative bases, namely: divergence in terms changes in energy prices and the introduction of tariffs for production, transportation, supply of heat and related district heating services and the center interim hot water; late compensation from the state budget of the difference in tariffs for heating energy, heating and hot water supply to the population, which arose due to the discrepancy between the actual cost of heat energy and the corresponding services set tariffs; decrease of the level of payments of the consumers of heat supply in the conditions of sharp increase of cost of the corresponding services for the population and decrease of its solvency; non-regulation of current legislation regarding obligations and requirements for customers of heat supply services in terms of timely payments.

Risk factors for the internal environment are primarily related to the main production activity of the MHC, such as unplanned shutdowns of equipment or interruption of the technological cycle of the MHC due to forced re-equipment, accidents, low level of technological discipline, etc.

Thus, the results of the scientific study have allowed to state that a harmonious combination of levers and instruments of a collaborative approach and a balanced system of indicators with consideration of environmental risk factors is the basis for a balanced management of relationships with stakeholders in utilities.

The study proposes to use the Balanced Scorecard (BSC) as one of the most successful enterprise management systems, which allows to evaluate the performance of the enterprise in the form of interrelated financial and non-financial indicators and to identify trends in each of the four key areas of activity to achieve the goal of MHC to meet the public needs of consumers for quality heating energy at the lowest cost, profit for the development of the enterprise, safeguarding the interests of its employees and meeting their economic and social needs on the basis of stakeholder reconciliation [10-14] (table 2). 
Table 2. Balanced scorecard for evaluating the effectiveness of managing relationships with stakeholders in municipal heating companies

\begin{tabular}{|c|c|c|c|}
\hline \multirow{2}{*}{\multicolumn{2}{|c|}{ Finances }} & $\begin{array}{c}\text { Strategic goals } \\
\end{array}$ & Quantitative and qualitative indicators of results \\
\hline & & $\begin{array}{l}\text { making profit that can be invested in } \\
\text { development }\end{array}$ & $\begin{array}{l}\text { - tariff for heating energy, UAH / Gcal and hot water } \\
\text { - the balance of outstanding compensation for the difference in } \\
\text { tariffs for heat } \\
\text { - compensation for losses arising from the difference between } \\
\text { actual costs and charges to consumers for services rendered } \\
\text { - financial assistance } \\
\text { - cost } 1 \text { Gcal of heating energy } \\
\text { - profitability level, \% } \\
\text { - business activity ratio }\end{array}$ \\
\hline \multicolumn{2}{|c|}{$\begin{array}{l}\text { Consumers of heating } \\
\text { energy and hot water } \\
\text { supply }\end{array}$} & $\begin{array}{l}\text { - increasing consumer satisfaction } \\
\text { - timely payment } \\
\text { - uninterrupted provision of district } \\
\text { heating services throughout the } \\
\text { heating season }\end{array}$ & $\begin{array}{l}\text { - tariff for heating energy for the needs of the population, UAH / } \\
\text { Gcal } \\
\text { - the period of collection of receivables for goods (works), } \\
\text { services } \\
\text { - the amount of money received for the heat released } \\
\text { - public debt (budgetary institutions, self-financing organizations) } \\
\text { - overall satisfaction with the enterprise } \\
\text { - evaluation of the quality of the services received } \\
\text { - number of consumer appeals } \\
\text { - the number of consumer complaints } \\
\text { - timely start and end of the heating season (for three days with an } \\
\text { average daily temperature of } 8{ }^{\circ} \mathrm{C} \text { ) } \\
\text { - indoor air temperature }(\text { subject to their insulation) meets current } \\
\text { rules and regulations - } 18^{\circ} \mathrm{C}\left(\text { in corner rooms - } 20^{\circ} \mathrm{C} \text { ) }\right.\end{array}$ \\
\hline \multirow{2}{*}{ 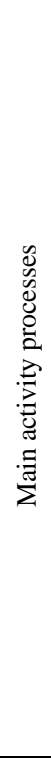 } & $\begin{array}{l}\text { for the production } \\
\text { of heating energy }\end{array}$ & $\begin{array}{l}\text { - cost reduction } \\
\text { - improving the quality of heat } \\
\text { supply } \\
\text { - ensuring reliable and trouble-free } \\
\text { operation of the enterprise } \\
\text { - reduction of losses in the course of } \\
\text { carrying out the activity } \\
\text { - reduction of natural gas } \\
\text { consumption } \\
\text { - reduction of harmful effects on the } \\
\text { environment }\end{array}$ & $\begin{array}{l}\text { - annual amount of heating energy useful leave, thousand Gcal. } \\
\text { - tariff for heat production, UAH / Gcal } \\
\text { - conditional fuel consumption per 1Gal of heating energy from } \\
\text { boiler houses } \\
\text { - electricity costs for the production of } 1 \mathrm{Gcal} \text { of heating energy } \\
\text { released from boiler houses } \\
\text { - water consumption for technological needs of production1Gcal } \\
\text { of heat released from boiler houses (without heating of heating } \\
\text { networks) } \\
\text { - accident in the heated season } \\
\text { - possibility of heat supply to consumers in due time } \\
\text { - reliability level of the heat supply system }\end{array}$ \\
\hline & $\begin{array}{l}\text { for the } \\
\text { transportation and } \\
\text { supply of heating } \\
\text { energy } \\
\text { (construction, } \\
\text { reconstruction and } \\
\text { modernization of } \\
\text { heat supply } \\
\text { facilities) }\end{array}$ & $\begin{array}{l}\text { - reduction of energy losses (heating } \\
\text { energy, fuel, electricity, etc.) } \\
\text { - ensuring the reliability of heating } \\
\text { networks }\end{array}$ & $\begin{array}{l}\text { - tariff for transportation of heating energy, UAH / Gcal } \\
\text { - tariff for heat supply, UAH / Gcal } \\
\text { - quantity of damages of heating networks, pcs. } \\
\text { - the amount of coolant leakage (including during the heating } \\
\text { period), } \\
\text { - annual transmission of heat networks, km. } \\
\text { - integrated dynamic efficiency of heat generation and } \\
\text { transportation }\end{array}$ \\
\hline \multirow{3}{*}{\multicolumn{2}{|c|}{$\begin{array}{l}\text { Training and } \\
\text { development of heat } \\
\text { supply workers }\end{array}$}} & $\begin{array}{l}\text { - enhancing production culture, } \\
\text { planning and delivery efficiency }\end{array}$ & $\begin{array}{l}\text { - labor turnover factor } \\
\text { - staffing ratio }\end{array}$ \\
\hline & & $\begin{array}{l}\text { - increase of efficiency of use of } \\
\text { labor resources } \\
\text { - ensuring the interests of employees } \\
\text { and meeting their economic and } \\
\text { social needs }\end{array}$ & $\begin{array}{l}\text { - productivity } \\
\text { - staffing, } \% \\
\text { - average monthly wage per employee }\end{array}$ \\
\hline & & - training of personnel & - coefficient of intellectual potential \\
\hline
\end{tabular}

The obtained system of indicators of performance evaluation of the relationship with the stakeholders of the MHC allows to calculate the indicator of integrated sustainable development of the MHC in the long run based on the management of the relationship with the stakeholders with the BSC, which reflects the success of the interaction of the MHC with key groups of stakeholders.
Methodical provisions for the evaluation of the indicator of the complex sustainable development of the MHC by BSC $(S j)$ are implemented using integral and partial indicators $\left(S_{i j}^{a}\right)$ according to the formulas $(1,2)$.

$$
S_{i j}^{\alpha}=\sum_{l=1}^{m} V_{i l}^{\alpha} \hat{p}_{l j}^{\alpha}
$$


where $\hat{p}_{i j}^{\alpha}=p_{i j}^{\alpha}-\bar{p}_{i j}^{\alpha}-$ centered indicators that characterize the impact of stake holders on the BSC; $V_{i l}^{\alpha}$ - eigenvectors for the group $\alpha(\alpha=1 . . s) ; m-$ the number of metrics in the group; $j$ - number of MHC.

An integral index is defined as a linear combination of group integral indicators:

$$
S_{j}=\sum_{\alpha=1}^{s} \beta_{\alpha} S_{1 j}^{\alpha},
$$

where $\beta \alpha$ - the significance coefficients of each group.

The results show that the implementation of the proposed approach within the framework of the analytical and applied support contributes to the improvement of the quality of the accepted alternatives for the development of MHC on the basis of ensuring communication of the management of the company with employees and external stakeholders in the field of heat supply with a non-random choice of complex measures for complex measures stakeholders.

\section{Conclusions}

According to the results of the research, the theoretical and methodological provisions of ensuring balanced management of the relations with the stakeholders of municipal heat supply enterprises have been improved.

On the basis of the systematization of the conceptual apparatus, the content of the concept of "stakeholders in the field of heat supply" is defined, which are defined as groups of subjects of relations that exert economic influence on the heat supplying enterprise connected with the production, transportation, supply and use of heating energy that have an actual impact. Management decisions in the enterprise may contribute to or hinder the achievement of the objectives of the enterprise, as well as limit its access to certain types of resources, or such influence may be potential, that result from operation, or groups of stakeholders.

The essence of the concept of "ensuring balanced management of relationships with stakeholders of municipal heat supply companies", which is considered as a set of processes and actions using methods, tools and management tools based on the coordination of interests of key stakeholder groups in the conduct of economic activity for making balanced management concepts model of organizational and methodological support for managing relations with MHC stakeholders in the sphere of heat supply.

The expediency of using a balanced scorecard as one of the most successful systems of enterprise management is substantiated, which allows to evaluate the performance of the enterprise in the form of interrelated financial and non-financial indicators and to determine the tendencies of change of each of four key spheres of activity in order to achieve the goal of MHC for meeting the needs of consumers on quality heating energy at the lowest cost, profit for the development of the enterprise, ensuring its interests employees and meeting their economic and social needs based on stakeholder reconciliation.

\section{References}

1. On heat supply: Law of Ukraine of June 2, 2005, Information of the Verkhovna Rada of Ukraine, 2005, No. 2633 -IV - Art. 373.

2. On the procedure for setting tariffs for the production, transportation, supply of heat and services for district heating and hot water supply : Resolution of the National Commission for Regulation in the Fields of Energy and Utilities of March 24, 2016 No. 377.

3. Mykytyuk, P. P. (2018), "Methodical approaches to the formation of the tariff policy of thermal energy production in the conditions of multi-fuel regime", Economic analysis, Vol. 28, No. 1, P. 79-86.

4. Brych, V. (2017), "Building a market for energy services: world experience and Ukrainian realities", Bulletin of the Ternopil National Economic University, P. 7-20.

5. Inyakin, V. N. (2006), "Ensuring stable functioning of housing and communal services", Scientific papers of Donetsk National Technical University. Series: Economic, Issue 30 (114), P. 132-139.

6. Kamyshnikova, E. V. (2016), "Collaborative approach to stakeholder management in the framework of corporate social responsibility", Problems and prospects of entrepreneurship development, No. 1, P. 84-88, available at: http://nbuv.gov.ua/UJRN/piprp_2016_1_15

7. Freeman, R. (1984), Edward Strategic management: a stakeholder approach, Pitman, 279 p.

8. Parfenenko, Yu. (2017), "The model of decision support in centralized heating management on the consumer side", Innovative Technologies and Scientific Solutions for Industries, No. 1 (1), P. 69-74. DOI: https://doi.org/10.30837/2522-9818.2017.1.069.

9. Kochan, T. A. (2000), "Toward a Stakeholder theory of the firm: the Saturn partnership", Organization Science, Vol. 11, No. 4, P. 367-386.

10. Bass, Yu. V. (2013), "The Stakeholder Concept in the Corporate Social Responsibility System", Management and Marketing, No. 4 (32), Vol. 2, P. 115-120.

11. Post, J. E., Preston, L., Sachs, S. (2002), Redefining the Corporation: Stakeholder Management and Organizational Wealth, Stanford University Press, California, 320 p.

12. Miroshnichenko, Yu. O. (2018), "A model of stakeholder interaction in the real economy of Ukraine in the context of CSR" Eastern Europe: Economics, Business and Management, Vol. 5, P. 71-74.

13. Wet, V.V. (2017), "Procedure for the analysis of enterprise stakeholders", Mukachevo State University, Vol. 12, P. $348-353$.

14. Strelkov, O. (2016), "Development of the enterprise due to the interests of stakeholders", East: Economic Sciences, No. 6 (146), P. 49-55.

15. AA1000 Stakeholder Engagement Standard (2015), 40 p. [On-line], available at: https://www.accountability.org/wpcontent/uploads/2016/10/AA1000SES_2015.pdf. 
Момот Тетяна Валеріївна - доктор економічних наук, професор, Харківський національний університет міського господарства імені О. М. Бекетова, завідувач кафедри фінансово-економічної безпеки, обліку і аудиту, Харків, Україна; email: tvmomot@gmail.com; ORCID: http://orcid.org/0000-0001-7397-3565.

Момот Татьяна Валерьевна - доктор экономических наук, профессор, Харьковский национальный университет городского хозяйства имени А. Н. Бекетова, заведующая кафедры финансово-экономической безопасности, учета и аудита, Харьков, Украина.

Momot Tetiana - Doctor of Sciences (Economics), Professor, O. M. Beketov National University of Urban Economy in Kharkiv, Head of the Department of Financial and Economic Security, Accounting and Auditing, Kharkiv, Ukraine.

Сінческул Ірина Леонідівна - Харківський національний університет міського господарства імені О. М. Бекетова, асистент кафедри економіки підприємств, бізнес-адміністрування та регіонального розвитку, Харків, Україна; email: Iryna.Sincheskul@kname.edu.ua; ORCID: http://orcid.org/0000-0003-3814-4045.

Синческул Ирина Леонидовна - Харьковская национальная академия городского хозяйства, асистент кафедры экономики предприятий, бизнес-администрирования и регионального развития, Харьков, Украина.

Sincheskul Irina - O. M. Beketov National University of Urban Economy in Kharkiv, Assistant Professor of the Department of Business Administration and Regional Development, Kharkiv, Ukraine.

Савенко Ксенія Сергіївна - кандидат економічних наук, Харківський національний економічний університет імені Семена Кузнеця, доцент кафедри міжнародного бізнесу та економічного аналізу, Харків, Україна; email: kseniasavenko13@gmail.com; ORCID: https://orcid.org/0000-0001-7458-1643.

Савенко Ксения Сергеевна - кандидат экономических наук, Харьковский национальный экономический университет имени Семена Кузнеца, доцент кафедры международного бизнеса и экономического анализа, Харьков, Украина.

Savenko Kseniia - PhD (Economics Sciences), Simon Kuznets Kharkiv National University of Economics, Associate Professor of the Department of International Business and Economic Analysis, Kharkiv, Ukraine.

Букрєєва Каріна Сергіївна - кандидат технічних наук, Національний технічний університет "Харківський політехнічний інститут", доцент кафедри стратегічного управління, Харків, Україна, email: karina.bukrieieva@gmail.com, ORCID: http://orcid.org/0000-0002-1199-7227.

Букреева Карина Сергеевна - кандидат технических наук, Национальный технический университет "Харьковский политехнический институт", доцент кафедры стратегического управления, Харьков, Украина.

Bukrieieva Karina - PhD (Project Management), National Technical University "Kharkiv Polytechnic Institute", Assosiate Professor at the Department of Strategic Management, Kharkiv, Ukraine.

\section{ЗБАЛАНСОВАНЕ УПРАВЛІННЯ ВЗАСМОВІДНОСИНАМИ ЗІ СТЕЙКХОЛДЕРАМИ У СФЕРІ ТЕПЛОПОСТАЧАННЯ}

Стаття присвячена дослідженню теоретичних засад і практичних аспектів управління взаємовідносинами зі стейкхолдерами теплопостачальних комунальних підприємств. Предметом дослідження є сукупність теоретичних, методичних і практичних аспектів щодо забезпечення збалансованого управління взаємовідносинами зі стейкхолдерами комунальних теплопостачальних підприємств. Метою статті $є$ розробка теоретико-методичних положень та обгрунтування практичних рекомендацій щодо забезпечення збалансованого управління цими взаємовідносинами. Завдання роботи: дослідити та систематизувати понятійний апарат забезпечення управління взаємовідносинами зі стейкхолдерами комунальних теплопостачальних підприємств; обгрунтувати організаційні засади управління цими взаємовідносинами; запропонувати аналітико-прикладне забезпечення управління ними за збалансованою системою показників. У ході дослідження використано методи: абстрактно-логічний аналіз, теоретичного узагальнення, системного та статистичного аналізу, системний та статистичний аналіз, економіко-математичні методи, графічний метод. В роботі узагальнено економічні характеристики діяльності теплопостачальних комунальних підприємств та розроблено напрямки розвитку взаємовідносин зі стейкхолдерами у процесі реформування житлово-комунального господарства України на основі аналізу ефективності діяльності теплопостачальних підприємств в розвинених країнах Європи. Обгрунтовані стратегічні напрямки розвитку теплопостачальних комунальних підприємств шляхом забезпечення збалансованого управління взаємовідносинами 31 стейкхолдерами. Висновки. Запропоновано застосовувати збалансовану систему показників, що дозволяє на основі оцінки фінансових і нефінансових індикаторів результативності діяльності підприємства визначити тенденції зміни кожної 3 чотирьох ключових сфер діяльності для досягнення мети КТП щодо задоволення суспільних потреб споживачів, одержання прибутку для розвитку підприємства, забезпечення інтересів його працівників та задоволення їх економічних і соціальних потреб на засадах узгодження інтересів стейкхолдерів.

Ключові слова: централізоване теплопостачання; комунальні теплопостачальні підприємства; управління взаємовідносинами; стейкхолдери; енергоефективність; організаційно-економічна модель.

\section{СБАЛАНСИРОВАННОЕ УПРАВЛЕНИЕ ВЗАИМООТНОШЕНИЯМИ СО СТЕЙКХОЛДЕРАМИ В СФЕРЕ ТЕПЛОСНАБЖЕНИЯ}

Статья посвящена исследованию теоретических основ и практических аспектов управления взаимоотношениями со стейкхолдерами теплоснабжающих коммунальных предприятий. Предметом исследования является совокупность теоретических, методических и практических аспектов по обеспечению сбалансированного управления взаимоотношениями со стейкхолдерами коммунальных теплоснабжающих предприятий. Целью статьи является разработка теоретико- 
методических положений и обоснование практических рекомендаций по обеспечению сбалансированного управления этими взаимоотношениями. Задачи работы: исследовать и систематизировать понятийный аппарат обеспечения управления взаимоотношениями со стейкхолдерами коммунальных теплоснабжающих предприятий; обосновать организационные основы управления этими взаимоотношениями; предложить аналитико-прикладное обеспечение управления ими сбалансированной системой показателей. В ходе исследования использованы методы: абстрактно-логический анализ, теоретического обобщения, системного и статистического анализа, системный и статистический анализ, экономикоматематические методы, графический метод. В работе обобщены экономические характеристики деятельности теплоснабжающих коммунальных предприятий и разработаны направления развития взаимоотношений со стейкхолдерами в процессе реформирования жилищно-коммунального хозяйства Украины на основе анализа эффективности деятельности теплоснабжающих предприятий в развитых странах Европы. Обоснованные стратегические направления развития теплоснабжающих коммунальных предприятий путем обеспечения сбалансированного управления взаимоотношениями со стейкхолдерами. Выводы. Предложено применять сбалансированную систему показателей, позволяет на основе оценки финансовых и нефинансовых индикаторов результативности деятельности предприятия определить тенденции изменения каждой из четырех ключевых сфер деятельности для достижения цели КТП по удовлетворению общественных потребностей потребителей, получение прибыли для развития предприятия, обеспечение интересов его работников и удовлетворение их экономических и социальных потребностей на основе согласования интересов стейкхолдеров.

Ключевые слова: централизованное теплоснабжение; коммунальные теплоснабжающие предприятия; управление взаимоотношениями; стейкхолдеры; энергоэффективность; организационно-экономическая модель.

\section{Бібліографічні описи / Bibliographic descriptions}

Момот Т. В., Сінческул І. Л., Савенко К. С., Букрєєва К. С. Збалансоване управління взаємовідносинами зі стейкхолдерами у сфері теплопостачання. Сучасний стан наукових досліджень та технологій в промисловості. 2019. № 4 (10). C. 101-110. DOI: https://doi.org/10.30837/2522-9818.2019.10.101.

Momot, T., Sincheskul, I., Savenko, K., Bukrieieva, K. (2019), "Balanced management of stakeholder relationships in the heating sphere", Innovative Technologies and Scientific Solutions for Industries, No.4 (10), P. 101-110. DOI: https://doi.org/10.30837/2522-9818.2019.10.101. 